\title{
AmyZ1: a novel a-amylase from marine bacterium Pontibacillus sp. ZY with high activity toward raw starches
}

\author{
Wei Fang ${ }^{1,2,3+} \mathbb{0}$, Saisai Xue ${ }^{1,2,3 \dagger}$, Pengjun Deng ${ }^{1,2,3}$, Xuecheng Zhang ${ }^{1,2,3}$, Xiaotang Wang ${ }^{4}$, Yazhong Xiao ${ }^{1,2,3^{*}}$ \\ and Zemin Fang ${ }^{1,2,3^{*}}$
}

\begin{abstract}
Background: Starch is an inexpensive and renewable raw material for numerous industrial applications. However, most starch-based products are not cost-efficient due to high-energy input needed in traditional enzymatic starch conversion processes. Therefore, a-amylase with high efficiency to directly hydrolyze high concentration raw starches at a relatively lower temperature will have a profound impact on the efficient application of starch.

Results: A novel raw starch digesting a-amylase (named AmyZ1) was screened and cloned from a deep-sea bacterium Pontibacillus sp. ZY. Phylogenetic analysis showed that AmyZ1 was a member of subfamily 5 of glycoside hydrolase family 13. When expressed in Escherichia coli, the recombinant AmyZ1 showed high activity at pH 6.0-7.5 and $25-50{ }^{\circ} \mathrm{C}$. Its optimal pH and temperature were 7.0 and $35^{\circ} \mathrm{C}$, respectively. Similar to most a-amylases, AmyZ1 activity was enhanced (2.4-fold) by $1.0 \mathrm{mM} \mathrm{Ca}^{2+}$. Its half-life time at $35^{\circ} \mathrm{C}$ was also extended from about 10 min to 100 min. In comparison, AmyZ1 showed a broad substrate specificity toward raw starches, including those derived from rice, corn, and wheat. The specific activity of AmyZ1 towards raw rice starch was 12,621 $\pm 196 \mathrm{U} / \mathrm{mg}$, much higher than other reported raw starch hydrolases. When used in raw starch hydrolyzing process, AmyZ1 hydrolyzed $52 \%, 47 \%$ and $38 \%$ of $30 \%(\mathrm{w} / \mathrm{v})$ rice, corn, and wheat starch after $4 \mathrm{~h}$ incubation. It can also hydrolyze marine raw starch derived from Chlorella pyrenoidosa, resulting in $50.9 \mathrm{mg} / \mathrm{g}$ DW (dry weight of the biomass) of reducing sugars after $4 \mathrm{~h}$ incubation at $35^{\circ} \mathrm{C}$. Furthermore, when hydrolyzing raw corn starch using the combination of AmyZ1 and commercial glucoamylase, the hydrolysis rate reached $75 \%$ after $4.5 \mathrm{~h}$ reaction, notably higher than that obtained in existing starch-processing industries.
\end{abstract}

Conclusions: As a novel raw starch-digesting a-amylase with high specific activity, AmyZ1 efficiently hydrolyzed raw starches derived from both terrestrial and marine environments at near ambient temperature, suggesting its application potential in starch-based industrial processes.

Keywords: a-Amylase, Specific activity, Raw starch hydrolysis, Pontibacillus sp.

\section{Background}

As one of the most abundant storage of carbohydrates, starch has been extensively employed as an inexpensive and renewable raw material for food, pharmaceutical, and bio-fuel industries [1]. Due to the polycrystalline structure in native starch granules [2],

\footnotetext{
*Correspondence: yzxiao@ahu.edu.cn; zemin_fang@ahu.edu.cn

${ }^{\dagger}$ Wei Fang and Saisai Xue contributed equally to this work

${ }^{1}$ School of Life Sciences, Anhui University, Hefei 230601, Anhui, China

Full list of author information is available at the end of the article
}

enzymatic hydrolyzation at a higher temperature is required to efficiently disrupt the native starch structure in starch-based industrial processes. Briefly, raw starch is sequentially gelatinized at about $100^{\circ} \mathrm{C}$, liquefied with thermophilic $\alpha$-amylases at about $95{ }^{\circ} \mathrm{C}$, and treated with glucoamylases at $50-60{ }^{\circ} \mathrm{C}[3,4]$. Apparently, existing starch processing techniques are energy-intensive, and thus it is necessary to develop more efficient and energyeffective processes. To solve this problem, $\alpha$-amylases 
capable of directly liquefying raw starch to glucose would have significant industrial implications.

$\alpha$-Amylase (EC 3.2.1.1) is one of the oldest and most important industrial enzymes used for starch processing [1]. The usage of $\alpha$-amylase digesting raw starch brings about $10-20 \%$ reduction in energy consumption compared to the traditional physical/chemical processes $[3,5]$. However, only approximately $10 \%$ of the known $\alpha$-amylases can efficiently digest raw starches directly to glucose because of their densely compacted architecture, large size, and unique surface profile [2, 3]. Furthermore, although many $\alpha$-amylases with raw starch hydrolyzing activity have been identified and characterized from bacteria and fungi, few of them possess high specific activity toward raw starches [6-9]. For example, the enzymes from Bacillus acidicola and Bacillus amyloliquefaciens exhibited $793 \mathrm{U} / \mathrm{mg}$ and $45 \mathrm{U} / \mathrm{mg}$ toward raw corn starch $[10,11]$. Other $\alpha$-amylases such as those from Geobacillus thermoleovorans [12], Rhizopus oryzae [13], and Thermomyces dupontii [14] possessed specific activities of no more than $2800 \mathrm{U} / \mathrm{mg}$. Therefore, it is essential to explore novel $\alpha$-amylases with higher specific activity toward raw starches to decrease the dosage and cost on the enzyme [15].

Another factor that hampers the application of $\alpha$-amylases is the low hydrolyzation efficiency towards high concentration raw starches. Typically, starch-processing industries employ 20-30\% (w/v) starch slurries [16]. Systematic studies with the enzymes from Bacillus licheniformis [16, 17], B. amyloliquefaciens [12], Bacillus subtilis [4, 17], and G. thermoleovorans [12, 18] have demonstrated that improved hydrolysis toward high concentration raw starches can be achieved by increasing the incubation temperature to $60^{\circ} \mathrm{C}$ or higher [19]. An alternative strategy to obtain better hydrolysis is to extend the reaction time at lower temperatures [16]. However, neither increasing temperature nor extending incubation time helps to reduce energy consumption and lower the cost of manufacturing. As a result, it is essential to explore novel $\alpha$-amylases that hydrolyze high concentration raw starches with high efficiency at a lower temperature.

Due to the complexity and diversity of the marine environment, the microbes in oceans are recognized as a tremendous treasure for the discovery of novel enzymes with unique properties. Several $\alpha$-amylases have been identified from the marine bacteria, including Bacillus aquimaris MKSC 6.2 [20], Geobacillus sp. 4j [17], B. subtilis S8-18 [4], Halothermothrix orenii [21], Aeromonas salmonicida [22], and a marine bacterial metagenome [2]. In this study, a bacterial strain with amylolytic activity was screened out from the sediment of Yongxing island and was named as Pontibacillus sp. ZY. A novel $\alpha$-amylase coding gene, designated as $A m y Z 1$, was successfully cloned from Pontibacillus sp. ZY and heterologously expressed in Escherichia coli. The recombinant enzyme AmyZ1 exhibited high specific activity and broad substrate specificity towards raw starches. Furthermore, AmyZ1 could efficiently hydrolyze high concentration raw starches at temperatures significantly lower than that used in current starch processing.

\section{Results and discussion}

\section{Screening for strains producing starch hydrolyzing enzymes}

After incubation at $15^{\circ} \mathrm{C}$ for 3 days, approximately 3600 colonies grew on the screen plates containing soluble starch. About 200 strains showed a halo around the colonies when the plates were stained with Lugol's iodine solution and were recognized as positive clones. One strain named ZY was chosen for further research because of its larger halo than other colonies.

Phylogenetic analysis suggested that the 16S rRNA gene of strain $\mathrm{ZY}$ showed $99 \%$ sequence identity to the marine bacteria Pontibacillus halophilus JSM 076056. Thus, this positive strain was named as Pontibacillus sp. ZY. Pontibacillus sp., implicating "Bacillus affiliated with the marine", was a novel genus identified for the first time in 2005 [23-25]. By 2018, only seven species were allocated to this genus (http://www.ezbiocloud.net/). Several novel enzymes have been identified and characterized from Pontibacillus sp., including protease and cytochrome P450 [26]. In comparison, only one amylase was partially purified from Pontibacillus sp. [27]. In this context, it is meaningful to characterize the properties of $\alpha$-amylase from the genus.

\section{Sequence analysis of AmyZ1}

A gene of $1521 \mathrm{bp}$, named $A m y Z 1$, was cloned from Pontibacillus sp. ZY. The deduced sequence encoded by $A m y Z 1$ contained a signal peptide comprising of 21 amino acid residues as predicted by SignalP and simple modular architecture research tool (SMART). The occurrence of a secretion signal in the deduced sequence was in agreement with the fact that AmyZ1 was secreted as an extracellular soluble protein in Pontibacillus sp. ZY. AmyZ1 showed the highest sequence identity of $99 \%$ (99\% similarity) with the $\alpha$-amylase from P. halophilus JSM 076056 , followed by $78 \%$ identity ( $88 \%$ similarity) with that from Pontibacillus chungwhensis. Both the enzymes were deduced from the whole-genome sequencing and have not been biochemically characterized previously.

AmyZ1 contained four conserved regions that are the typical characteristics of the glycoside hydrolase family 13 (GH13) [28] (Additional file 1: Figure S1). The catalytic 
triad of Asp234, Glu264, and Asp331 were located in regions I, II, and III, respectively (Additional file 1: Figure S1). Based on the phylogenetic analysis, AmyZ1 was branched together with the enzymes from subfamily 5 of GH13 (GH13_5) (Additional file 2: Figure S2). In fact, AmyZ1 was recorded by CAZy as the first GH13_5 $\alpha$-amylase that derived from the genus Pontibacillus. The GH13_5 mainly contains liquefying $\alpha$-amylases from different marine bacterial sources, such as Bacillus sp. YX-1, B. amyloliquefaciens, Bacillus cereus and B. licheniformis $\mathrm{NH} 1[28,29]$. In addition, GH13_5 also contains the typical terrestrial $\alpha$-amylase from $B$. licheniformis isolated from soil. The AmyZ1 structure was obtained by homology modeling using the $\alpha$-amylase from $B$. licheniformis (PDB code: $1 \mathrm{BLI}$, shared $71 \%$ identity and $83 \%$ similarity with AmyZ1) as the template. Results showed that AmyZ1 was comprised of three domains, including catalytic domain A, followed by domain B and C (Additional file 3: Fig. S3).

\section{Expression and refolding of AmyZ1}

The recombinant enzyme AmyZ1 was expressed as inclusion bodies even after expression condition optimization, including the initial induction $O D_{600}$, isopropyl $\beta$-D-1thiogalactopyranoside (IPTG) concentration, induction time, and incubation temperature. Fortunately, AmyZ1 can be easily refolded to its active form following the protocol described in "Methods" section. As shown in Additional file 4: Table S1, AmyZ1 was 1.3-fold purified to homology with $29.4 \%$ recovery. The purified enzyme displayed a single band on sodium dodecyl sulfate polyacrylamide gel electrophoresis (SDS-PAGE) (Fig. 1a), with an apparent molecular weight of about $55 \mathrm{kDa}$, consistent with the theoretical value calculated based on the amino acid sequence. Native-PAGE showed that AmyZ1 exhibited a molecular weight of about $240 \mathrm{kDa}$, that the active protein is a homotetramer (Fig. 1b).

\section{Biochemical characterization of AmyZ1}

With raw rice starch as the substrate, AmyZ1 exhibited the highest activity at $\mathrm{pH} 7.0$ in both citrate- $\mathrm{Na}_{2} \mathrm{HPO}_{4}$ and $\mathrm{Na}_{2} \mathrm{HPO}_{4}-\mathrm{KH}_{2} \mathrm{PO}_{4}$ buffers (Fig. 2a). However, AmyZ1 displayed higher specific activity in $\mathrm{Na}_{2} \mathrm{HPO}_{4}{ }^{-}$ $\mathrm{KH}_{2} \mathrm{PO}_{4}$ buffer than that in citrate- $\mathrm{Na}_{2} \mathrm{HPO}_{4}$ buffer. As a result, the $\mathrm{Na}_{2} \mathrm{HPO}_{4}-\mathrm{KH}_{2} \mathrm{PO}_{4}$ buffer was selected in the following tests. As shown in Fig. 2a, AmyZ1 possessed more than $87 \%$ maximum activity in the range of $\mathrm{pH} 6.0$ 7.5 in $50 \mathrm{mM} \mathrm{Na}_{2} \mathrm{HPO}_{4}-\mathrm{KH}_{2} \mathrm{PO}_{4}$ buffer.

AmyZ1 showed the highest activity at $35{ }^{\circ} \mathrm{C}$ and maintained more than $80 \%$ of residue activity at the range from 30 to $50{ }^{\circ} \mathrm{C}$ (Fig. 2b). Furthermore, AmyZ1 showed more than $40 \%$ of the highest activity at $20{ }^{\circ} \mathrm{C}$, indicating the "cold-active" catalytic ability (Fig. 2b). It has been

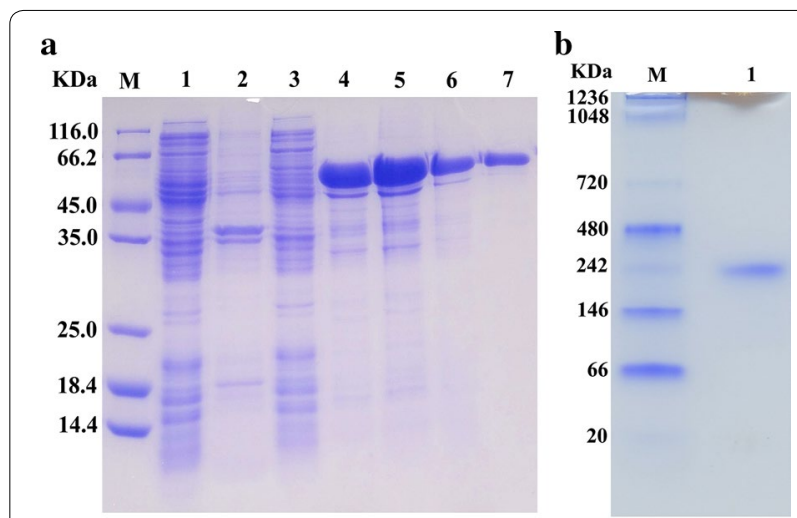

Fig. 1 SDS-PAGE and Native-PAGE analysis of AmyZ1. a SDS-PAGE. M: protein molecular weight marker (Thermo Fisher Scientific, Inc.); lane 1 and 2: the sonication supernatant and precipitate of E. coli harboring plasmid pET22b(+)-AmyZ1 without induction; lane 3 and 4: the sonication supernatant and precipitate of $E$. coli harboring plasmid pET22b(+)-AmyZ1 induced by IPTG; lane 5: the protein denaturated by $8 \mathrm{M}$ urea; lane 6 : the protein after renaturation; lane 7: the target protein after dialysis. b Native-PAGE analysis of the purified AmyZ1. M: native protein molecular weight marker (Thermo Fisher Scientific, Inc.); lane 1: the purified native protein

widely believed that most marine $\alpha$-amylases possess a narrow range of optimum $\mathrm{pHs}$ and optimum temperatures [29]. However, AmyZ1 retained most of its activity in a broad $\mathrm{pH}$ and temperature range, implicating its great application potential in the starch processing industry.

AmyZ1 was more stable at $\mathrm{pH} 6.5$ than that at $\mathrm{pH} 6.0$ and $\mathrm{pH} 7.0$ (Fig. 2c). It exhibited poor pH- and thermostability in the absence of $\mathrm{Ca}^{2+}$, with about $60 \%$ of the activity was lost within $10 \mathrm{~min}$ at $35{ }^{\circ} \mathrm{C}$ and $\mathrm{pH} 6.5$ (Fig. 2d). The half-life of AmyZ1 at $30{ }^{\circ} \mathrm{C}$ and $\mathrm{pH} 6.5$ was only about $12 \mathrm{~min}$ (Fig. 2d). In comparison, the introduction of $\mathrm{Ca}^{2+}$ significantly improved AmyZ1 catalytic activity and stability. AmyZ1 activity was enhanced to a maximum value of more than 2.4-fold in the presence of $1.0 \mathrm{mM} \mathrm{Ca}^{2+}$ compared to that without $\mathrm{Ca}^{2+}$ addition at $35^{\circ} \mathrm{C}$ (Fig. 3a). Furthermore, the halflife of AmyZ1 at $35{ }^{\circ} \mathrm{C}$ was increased to approximately $100 \mathrm{~min}$, approaching 10-fold longer than the time without $\mathrm{Ca}^{2+}$ addition (Fig. 3b). When incubated at $30{ }^{\circ} \mathrm{C}$, AmyZ1 retained more than $50 \%$ residual activity after $15 \mathrm{~h}$ incubation in the presence of $1.0 \mathrm{mM} \mathrm{Ca}{ }^{2+}$ (Additional file 5: Fig. S4). Thus, AmyZ1 was relatively stable at lower temperatures, similar to some marinederived $\alpha$-amylases [30-33]. These enzymes may be beneficial to be applied in the processes that enzyme is required to be completely inactivated with increasing temperatures [30, 34].

On the other hand, similar to AmyZ1, $\mathrm{Ca}^{2+}$ could improve the activity and thermostability of some 

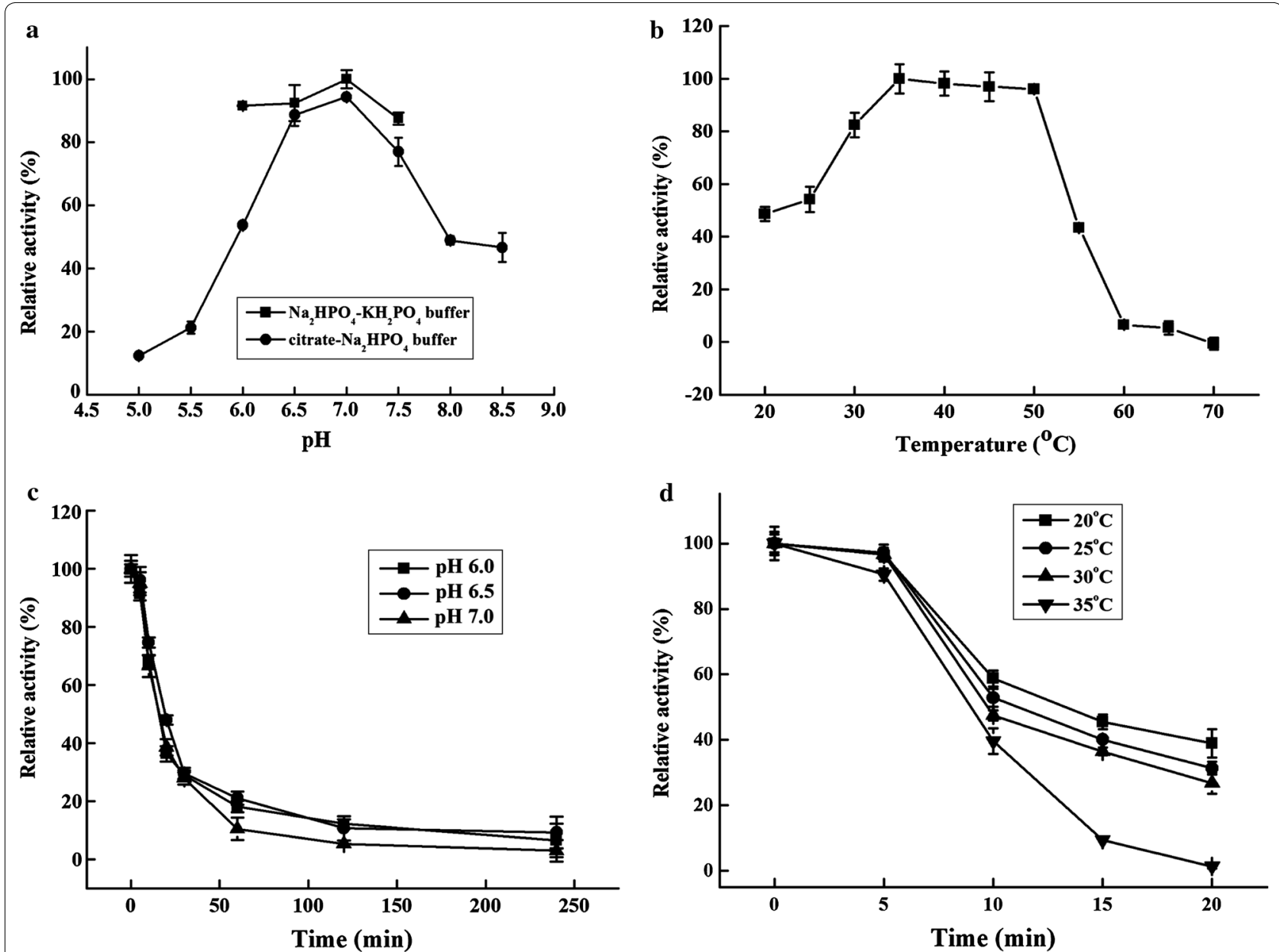

Fig. 2 Effects of $\mathrm{pH}$ and temperature on AmyZ1 activity $(\mathbf{a}, \mathbf{b})$ and stability $(\mathbf{c}, \mathbf{d})$. a Optimum pH of AmyZ1. With raw rice starch as the substrate, the optimum $\mathrm{pH}$ was determined in citrate- $\mathrm{Na}_{2} \mathrm{HPO}_{4}$ buffer $\left(50 \mathrm{mM}, \mathrm{pH}\right.$ 5.0-8.5) and $\mathrm{Na}_{2} \mathrm{HPO}_{4}-\mathrm{KH}_{2} \mathrm{PO}_{4}$ buffer (50 mM, pH 6.0-7.5). b Optimum temperature of AmyZ1. The assays were measured at temperatures from 20 to $70{ }^{\circ} \mathrm{C}$ in $\mathrm{Na}_{2} \mathrm{HPO}_{4}-\mathrm{KH}_{2} \mathrm{PO}_{4}$ buffer $(50 \mathrm{mM}$, pH7.0). c Effect of pH on enzyme stability. The purified enzyme was incubated in $50 \mathrm{mM} \mathrm{Na}_{2} \mathrm{HPO}_{4}-\mathrm{KH}_{2} \mathrm{PO}_{4}$ buffer $(\mathrm{pH} 6.0-7.0)$ at $30^{\circ} \mathrm{C}$ and the remaining activities were measured at appropriate intervals. $\mathbf{d}$ Effect of temperature on enzyme stability. The purified enzyme was incubated at $20-35^{\circ} \mathrm{C}$ in $\mathrm{Na}_{2} \mathrm{HPO}_{4}-\mathrm{KH}_{2} \mathrm{PO}_{4}$ buffer $(50 \mathrm{mM}, \mathrm{pH}$ 6.5). The remaining activities was determined at appropriate intervals. All the results were the average of triplicate experiments

$\alpha$-amylases. For example, the $\alpha$-amylases from $B$. licheniformis [6] and Bacillus stearothermophilus [35] displayed improved activity and stability in the presence of $\mathrm{Ca}^{2+}$. Based on the crystal structure of $\alpha$-amylase from $B$. licheniformis, $\mathrm{Ca}^{2+}$ was speculated to play an important role in establishing a $\mathrm{Ca}^{2+}-\mathrm{Na}^{+}-$ $\mathrm{Ca}^{2+}$ connection in the interior of domain $\mathrm{B}$, and stabilizing the architecture of the catalytic cleft [36-38]. Furthermore, the presence of an extra $\mathrm{Ca}^{2+}$-binding region at the interface between domains $\mathrm{A}$ and $\mathrm{C}$ is also believed to be responsible for a higher stability of the enzyme [38].

Other metal ions such as $\mathrm{Na}^{+}$and $\mathrm{K}^{+}$also stimulated the activity of AmyZ1 at concentrations used in our test. For instance, $\mathrm{Na}^{+}$stimulated AmyZ1 activity with a maximal increase of approximately 1.4-fold, whereas the enzyme stability was improved slightly (Fig. 3c, d). While $\mathrm{Mg}^{2+}, \mathrm{Zn}^{2+}, \mathrm{Mn}^{2+}$, and $\mathrm{Cu}^{2+}$ drastically impaired the enzyme activity (Additional file 6: Table S2). Generally, $\mathrm{Cu}^{2+}$ and $\mathrm{Zn}^{2+}$ were reported to be inhibitors of $\alpha$-amylases, such as the enzymes from Exiguobacterium sp. [39], B. licheniformis [40], B. subtilis [41], and Luteimonas abyssi [42]. The chelating agent EDTA showed an inhibitory effect on the activity of AmyZ1, further supporting the fact that AmyZ1 was a metalloenzyme.

\section{Substrate specificity}

The substrate specificity of AmyZ1 towards raw starches was investigated using various types of substrates (Table 1). Although AmyZ1 showed negligible activities 

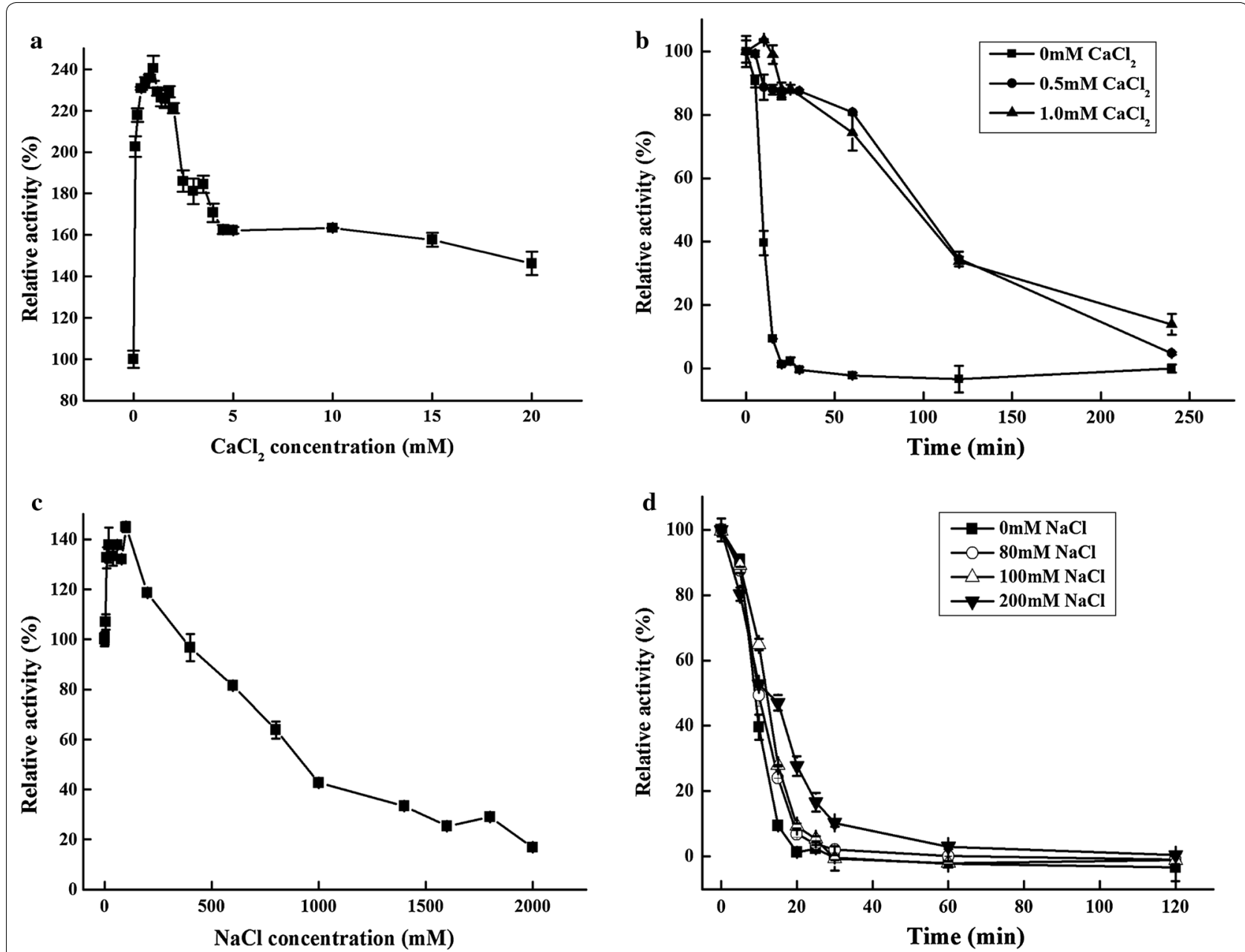

Fig. 3 Effects of $\mathrm{CaCl}_{2}$ and $\mathrm{NaCl}$ on AmyZ1 activity $(\mathbf{a}, \mathbf{c})$ and stability $(\mathbf{b}, \mathbf{d})$. For the effect on enzyme activity, the assays were carried out at $35^{\circ} \mathrm{C}$ with additional supplement of $\mathrm{CaCl}_{2}$ or $\mathrm{NaCl}$. For the effect on enzyme stability, the assays were performed by incubating the enzyme at $35^{\circ} \mathrm{C}$ in $\mathrm{Na}_{2} \mathrm{HPO}_{4}-\mathrm{KH}_{2} \mathrm{PO}_{4}$ buffer $\left(50 \mathrm{mM}\right.$, pH 7.0) containing $\mathrm{CaCl}_{2}$ or NaCl. The residual activities were determined at various time intervals. All the results were the average of triplicate experiments

Table 1 Substrate specificities of Amyz1 toward raw starches and soluble starches

\begin{tabular}{llll}
\hline & Source & $\begin{array}{l}\text { Specific } \\
\text { activities } \\
\text { (U/mg) }\end{array}$ & $\begin{array}{l}\text { Relative } \\
\text { activities } \\
\text { (\%) }\end{array}$ \\
\hline Raw starches & Rice (A type) & $12,621 \pm 196$ & 100 \\
& Corn (A type) & $9055 \pm 251$ & 72 \\
& Wheat (A type) & $5158 \pm 133$ & 41 \\
& Barley (A type) & $4872 \pm 146$ & 39 \\
& Potato (B type) & $2623 \pm 239$ & 21 \\
& Bean (C type) & $1009 \pm 42$ & 8 \\
Soluble starches & Soluble starch & $14,815 \pm 310$ & 117 \\
& Amylose & $14,428 \pm 111$ & 114 \\
& Amylopectin & $23,626 \pm 367$ & 187 \\
\hline
\end{tabular}

toward pullulan, $\alpha$-cyclodextrin, and $\beta$-cyclodextrin, it could hydrolyze a broad range of raw starch granules including A, B, and $\mathrm{C}$ types. Particularly, different from most $\alpha$-amylases that preferred wheat and corn raw starches as the favorite substrates [2], AmyZ1 preferentially hydrolyzed raw rice starch. It exhibited the highest specific activity of $12,621 \pm 196 \mathrm{U} / \mathrm{mg}$ towards rice raw starch, followed by corn and wheat raw starch. The $K_{\mathrm{m}}$ and $V_{\max }$ of AmyZ1 were $8.85 \pm 0.44 \mathrm{mg} / \mathrm{mL}$ and $17,837 \pm 440 \mathrm{U} / \mathrm{mg}$ using raw rice starch as the substrate. The marine $\alpha$-amylase AmyP also preferred rice raw starch as the substrate [2]. However, the specific activity of AmyZ1 was about 106-fold higher than that of AmyP (Table 2). AmyZ1 also showed higher specific activity than that of the enzymes derived from bacteria, fungi, and yeast. As shown in Table 2, few enzymes 
Table 2 Specific activities of AmyZ1 and other known a-amylases toward soluble starches and raw starches

\begin{tabular}{|c|c|c|c|c|c|c|}
\hline \multirow[t]{2}{*}{ Source (enzyme name) } & \multicolumn{5}{|c|}{ Specific activity (U/mg) } & \multirow[t]{2}{*}{ Refs } \\
\hline & Soluble starch & Rice & Corn & Wheat & Potato & \\
\hline \multicolumn{7}{|l|}{ Bacteria } \\
\hline Bacillus licheniformis 9945a (BliAmy) & 3667 & NM & NM & NM & NM & [49] \\
\hline Luteimonas abyssi XH031T (LaaA) & 8881 & NM & NM & NM & NM & {$[42]$} \\
\hline Bacillus licheniformis AS08E (Blamy-I) & 1063 & NM & NM & NM & NM & {$[50]$} \\
\hline Bacillus sp. UEB-S & 900 & NM & NM & NM & NM & [51] \\
\hline Streptomyces badius DB-1 & 247 & 156 & 148 & 212 & NM & {$[52]$} \\
\hline Geobacillus thermoleovorans (Gt-amy) & 1723 & 1049 & 2076 & 2371 & NM & [12] \\
\hline Geobacillus sp. (Gs4j-amyA) & 8600 & NM & NM & NM & NM & [17] \\
\hline Bacillus amyloliquefaciens & 72 & 31 & 45 & 40 & 68 & [10] \\
\hline Aeromonas salmonicida (AmyASS) & 45 & 52 & NM & 5 & NM & [22] \\
\hline $\begin{array}{l}\text { Marine bacterial metagenomes (AmyP) (unknown } \\
\text { marine bacterium) }\end{array}$ & NM & 119 & NM & 7 & 12 & {$[2]$} \\
\hline Bacillus acidicola & 1166 & 875 & 793 & 979 & NM & [11] \\
\hline Bacillus sp. YX-1 & NM & NM & NM & NM & 607 & [53] \\
\hline Corallococcus sp. strain EGB (AmyM) sp. Strain EGB & 14,000 & NM & NM & NM & NM & {$[54]$} \\
\hline Pontibacillus sp. ZY (AmyZ1) & 14,815 & 12,621 & 9056 & 5158 & 2623 & This study \\
\hline \multicolumn{7}{|l|}{ Fungi } \\
\hline Aspergillus penicillioides & 118 & NM & NM & NM & NM & [43] \\
\hline Aspergillus oryzae cmc1 & 32 & NM & NM & NM & NM & [44] \\
\hline Aspergillus oryzae $\mathrm{cmc} 1$ mutant $\mathrm{M}-100(6)$ & 2461 & NM & NM & NM & NM & [44] \\
\hline Aspergillus oryzae strain S2 (rAmyA) & 5150 & NM & NM & NM & NM & [45] \\
\hline Rhizopus oryzae (RoAmy) & 1123 & 1044 & 1449 & 1494 & 1089 & [13] \\
\hline Thermomyces dupontii (TdAmyA) & 2814 & 2339 & 2709 & 2417 & 1315 & [14] \\
\hline \multicolumn{7}{|l|}{ Yeast } \\
\hline Cryptococcus flavus (rAmy1) & $4165^{a}$ & NM & NM & NM & NM & {$[46]$} \\
\hline Cryptococcus flavus & $843^{b}$ & NM & NM & NM & NM & [47] \\
\hline Cryptococcus sp. S-2 & 2539 & NM & NM & NM & NM & [9] \\
\hline Saccharomycopsis fibuligera (Sfamy KZ) & 120 & $91^{c}$ & $98^{\mathrm{d}}$ & NM & NM & {$[48]$} \\
\hline
\end{tabular}

Enzyme activity was measured by DNS method. One unit of amylase activity was defined as the amount of enzyme needed to release $1 \mu$ mol of reducing sugars as maltose per minute

NM not mentioned

a One unit was defined as the amount of enzyme necessary to produce $1 \mathrm{mg}$ glucose equivalent/min

b One unit of amylase activity was defined as the amount of enzyme necessary to hydrolyze $0.1 \mathrm{mg}$ starch per minute

$c, d$ The substrates were boiled

exhibited specific activity exceeding $1000 \mathrm{U} / \mathrm{mg}$ toward raw starches, e.g. Gt-amy from the extreme thermophile $G$. thermoleovorans [12], RoAmy from $R$. oryzae [13], and TdAmyA from the thermophilic fungus T. dupontii [14]. In addition, these enzymes were optimally active at $50{ }^{\circ} \mathrm{C}$ or higher. Obviously, AmyZ1 was superior to them not only because of its higher specific activity but also its lower temperature needed for reactions.

AmyZ1 showed the specific activities of up to $23,626 \pm 367$ and $14,428 \pm 111 \mathrm{U} / \mathrm{mg}$, respectively, toward amylopectin than amylose, indicating that the enzyme was able to hydrolyze both $\alpha-1,4$ and $\alpha-1,6$ glycosidic linkages with high efficiency (Table 1). However, this phenomenon is abnormal for $\alpha$-amylases because they generally display higher activities toward amylose than that of amylopectin $[2,11,42,51,52]$. As listed in Table 2, the specific activity of AmyZ1 toward soluble starch was up to $14,815 \pm 310 \mathrm{U} / \mathrm{mg}$, higher than that of AmyM, an $\alpha$-amylase from the soil bacterium Corallococcus sp. Strain EGB, which was reported in 2015 as the most efficient soluble starch hydrolyzing enzyme [54]. Furthermore, AmyM did not exhibit the raw starch hydrolysis ability [54]. The fact that AmyZ1 could efficiently break both $\alpha-1,4$ and $\alpha-1,6$ glycosidic linkages may explain why AmyZ1 possessed higher catalytic activity toward soluble starch than other $\alpha$-amylases do. 


\section{Hydrolysis toward high concentration raw starches}

The starch-processing industries usually employ $20-30 \%$ concentration starch slurries as the starting substrates [16]. Thus, raw starch hydrolysis property of AmyZ1 was assayed under 30\% starch concentration (Fig. 4). After hydrolyzation condition optimization, the AmyZ1 dosages employed were $5 \mathrm{U} / \mathrm{mg}$ raw rice or wheat starch, and $1 \mathrm{U} / \mathrm{mg}$ raw corn starch. The optimized hydrolyzation temperatures were $35{ }^{\circ} \mathrm{C}$ for raw rice starch and $30{ }^{\circ} \mathrm{C}$ for raw corn or wheat starch. As shown in Fig. $4 \mathrm{~d}$, the hydrolysis process displayed a classical two-phase shape, with a rapid initial reaction phase, followed by a slower stage. The most efficient hydrolysis was obtained within the first $4 \mathrm{~h}$. Only a slight increase in reducing sugars was observed after extending the incubation time from 4 to $24 \mathrm{~h}$. After $4 \mathrm{~h}$ incubation, the reducing sugars reached $157.1 \pm 1.7 \mathrm{mg} / \mathrm{mL}, 141.8 \pm 3.3 \mathrm{mg} / \mathrm{mL}$, and $112.4 \pm 0.2 \mathrm{mg} / \mathrm{mL}$ with raw rice, corn, and wheat starch as the substrate, respectively. Correspondingly, the hydrolysis rates were $52.4 \pm 2.9 \%, 47.3 \pm 1.1 \%$ and $37.5 \pm 1.1 \%$ for raw rice, corn, and wheat starch.

Due to some limiting factors including the surface morphology and crystalline structure of starch granules [56], only a few $\alpha$-amylases were reported to possess the ability to hydrolyze raw starch slurries at concentrations higher than $15 \%$ (Table 3). The temperature is a critical factor influencing the hydrolysis of raw starch slurries at high concentrations. To reach a higher hydrolyzation efficiency, a relatively higher temperature $\left(\geq 60^{\circ} \mathrm{C}\right)$ is usually employed in starch conversion processes, where some commercial thermophilic $\alpha$-amylases are used, such as those from B. amyloliquefaciens [17], B. licheniformis
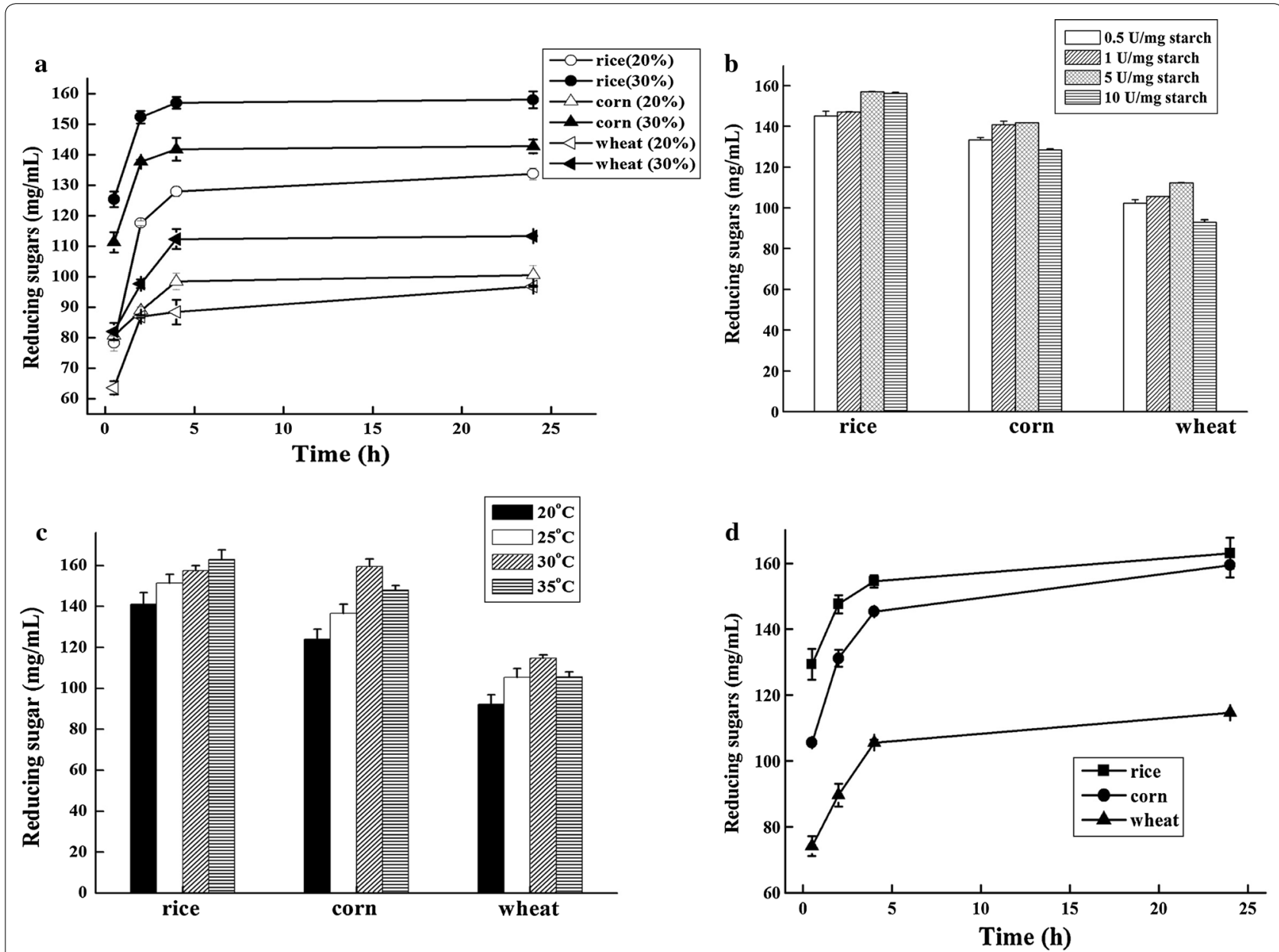

Fig. 4 Optimization of hydrolysis conditon toward raw starches from corn, wheat, and rice. a Substrate concentrations. The reaction mixture contained $20 \%$ or $30 \%$ raw starches, and $5 \mathrm{U} / \mathrm{mg}$ starch of AmyZ1. The assays was performed at $30^{\circ} \mathrm{C}$ and $150 \mathrm{rpm}$ for $24 \mathrm{~h}$. b Enzyme dosage. With 30\% raw starches as the substrates, the reaction mixture contained $0.5-10 \mathrm{U} / \mathrm{mg}$ starch of AmyZ1 as the catalyst. c Reaction temperature. The reaction mixture contained $30 \%$ raw starch slurry and appropriate units of AmyZ1. The assays was performed at $20-35^{\circ} \mathrm{C}$. $\mathbf{d}$ Time course of the reaction catalyzed by AmyZ1. All the results were the average of triplicate experiments 
Table 3 Hydrolysis rates of AmyZ1 and other known a-amylases with high concentration raw starches as the substrates

\begin{tabular}{|c|c|c|c|c|c|c|}
\hline \multirow[t]{2}{*}{ Source (enzyme name) } & \multicolumn{2}{|c|}{ Degree of hydrolysis (\%) } & \multirow{2}{*}{$\begin{array}{l}\text { Enzyme amount } \\
\text { (U mg }{ }^{-1} \text { starch) }\end{array}$} & \multirow[t]{2}{*}{$\operatorname{Temp}\left({ }^{\circ} \mathrm{C}\right)$} & \multirow[t]{2}{*}{$\mathrm{pH}$} & \multirow[t]{2}{*}{ Refs } \\
\hline & Wheat & Corn & & & & \\
\hline \multicolumn{7}{|l|}{ Bacteria } \\
\hline Bacillus aquimaris MKSC 6.2 (BaqA) & NM & $1.4 \%(10 \%$ and $24 \mathrm{~h})$ & $2^{\mathrm{a}}$ & 37 & 6.5 & {$[20]$} \\
\hline Bacillus sp. YX-1 & NM & $50 \%(20 \%$ and $12 \mathrm{~h})$ & 0.3 & 50 & 5.0 & [53] \\
\hline Geobacillus thermoleovorans (Gt-amy) & $26 \%(30 \%$ and $3 \mathrm{~h})$ & $24 \%(30 \%$ and $3 \mathrm{~h})$ & 0.1 & 60 & 5.0 & [12] \\
\hline Geobacillus thermoleovorans (Gt-amyll) & NM & $31 \%(30 \%$ and $3 h)$ & 70.0 & 50 & 7.0 & [18] \\
\hline Nesterenkonia sp. strain F & $10 \%(15 \%$ and $48 \mathrm{~h})$ & NM & NM & 45 & NM & {$[55]$} \\
\hline Geobacillus sp. 4j (Gs4j-amyA) & $45 \%$ (30\% and $4 \mathrm{~h})$ & $36 \%(30 \%$ and $4 \mathrm{~h})$ & 0.5 & 65 & 5.5 & [17] \\
\hline Bacillus amyloliquefaciens (BAA, Sigma) & $50 \%(30 \%$ and $4 \mathrm{~h})$ & $15 \%(30 \%$ and $4 \mathrm{~h})$ & 0.5 & 65 & 5.5 & [17] \\
\hline Bacillus licheniformis (BLA, Sigma) & $50 \%(30 \%$ and $4 \mathrm{~h})$ & $35 \%(30 \%$ and $4 \mathrm{~h})$ & 0.5 & 65 & 5.5 & [17] \\
\hline Bacillus licheniformis (BLA, Sigma) & NM & $58 \%(30 \%$ and $5 \mathrm{~h})$ & 11.5 & 60 & 6.5 & [16] \\
\hline Bacillus licheniformis ATCC9945a (BliAmy) & NM & $58 \%(30 \%$ and $5 \mathrm{~h})$ & 11.5 & 60 & 6.5 & {$[16]$} \\
\hline Bacillus licheniformis (BLA, Sigma) & $35 \%(30 \%$ and $4 h)$ & $43 \%(30 \%$ and $4 h)$ & 1.0 & 30 & 7.0 & This study \\
\hline Pontibacillus sp. ZY (AmyZ1) & $37 \%(30 \%$ and $4 \mathrm{~h})$ & $47 \%(30 \%$ and $4 \mathrm{~h})$ & $5.0^{b}$ or $1.0^{c}$ & 30 & 7.0 & This study \\
\hline \multicolumn{7}{|l|}{ Fungi and other } \\
\hline Rhizomucorsp. (RA) & NM & $75 \%(31 \% \text { and } 96 h)^{d}$ & 15.5 & 32 & 4.5 & [56] \\
\hline Porcine pancreas (PPA) & NM & $32 \%(31 \% \text { and } 96 h)^{d}$ & 15.5 & 37 & 7.0 & {$[56]$} \\
\hline
\end{tabular}

NM not mentioned

${ }^{\mathrm{a}} \mu \mathrm{g} / \mathrm{mg}$

b With raw wheat starch as the substrate

c With raw corn starch as the substrate

d Total solubilized sugars were measured in the supernatant by the orcinol sulfuric method

[17], and G. thermoleovorans $[12,18]$ (Table 3). Another way to reach a higher hydrolysis rate is to extend incubation time at a lower temperatures $\left(\leq 50^{\circ} \mathrm{C}\right)$ and using the mesophilic enzymes from Bacillus sp. YX-1 [53], Nesterenkonia sp. strain F [55], and Rhizomucor sp. [56] as the catalysts (Table 3). Neither increasing temperature nor extending incubation time could help to reduce energy consumption and lower the cost of manufacturing. Compared to the enzymes listed above, AmyZ1 offers the advantages of efficiently hydrolyzing raw starches at a lower temperature within a shorter reaction time.

On the other hand, less enzyme unit of AmyZ1 was needed to achieve better hydrolyzation towards high concentration raw corn starches. In comparison, more enzyme units were required in the reaction mixture to obtain higher hydrolysis rates, such as $70.0 \mathrm{U} / \mathrm{mg}$ starch of Gt-amyII from G. thermoleovorans, $15.5 \mathrm{U} / \mathrm{mg}$ starch of $\alpha$-amylase from Rhizomucor sp., and $11.5 \mathrm{U} / \mathrm{mg}$ starch of enzyme from $B$. licheniformis (Table 3). Furthermore, due to its high specific activity, less protein of AmyZ1 was required in the reaction. In this context, the usage of AmyZ1 would help to reduce the dosage and cost of the enzyme.

Although carbohydrate-rich feedstocks are currently used as raw materials for bioethanol production, algae are considered to be the future feedstock because of their high carbohydrate content and absence of lignin compared to higher plants [57, 58]. Chlorella sp. has been recognized as one of the best feedstock candidates for bioethanol production, because of its high starch and cellulose content [59]. When AmyZ1 was used to hydrolyze the pretreated C. pyrenoidosa, $50.9 \pm 0.9 \mathrm{mg} / \mathrm{g} \mathrm{DW}$ (dry weight of the biomass) of reducing sugars were produced after $4 \mathrm{~h}$ incubation at $35{ }^{\circ} \mathrm{C}$ with an enzyme dosage of $5 \mathrm{U} / \mathrm{mg}$ biomass (Fig. 5b). The reducing sugars released by AmyZ1 approached to the results of acid hydrolysis of Chlorella sorokiniana as reported by Hernández et al. [57], although it was lower than that of the combination of acid hydrolysis followed by enzymatic hydrolysis or the combination of various commercial enzymes as a compounded catalyst $[57,59]$.

\section{Efficient hydrolysis of raw corn starch with AmyZ1 and the commercial glucoamylase}

AmyZ1 was used to hydrolyze raw corn starch without the gelatinization process of starch. After incubation at $30{ }^{\circ} \mathrm{C}$ for $4 \mathrm{~h}$, AmyZ1 hydrolyzed $47.3 \pm 1.1 \%$ of the starch in raw corn flour (Fig. 6). After the mixture was further treated with commercial glucoamylase from Aspergillus niger for $0.5 \mathrm{~h}$, the hydrolysis rate reached $74.8 \pm 0.7 \%$ and reached $78.3 \pm 1.1 \%$ after 

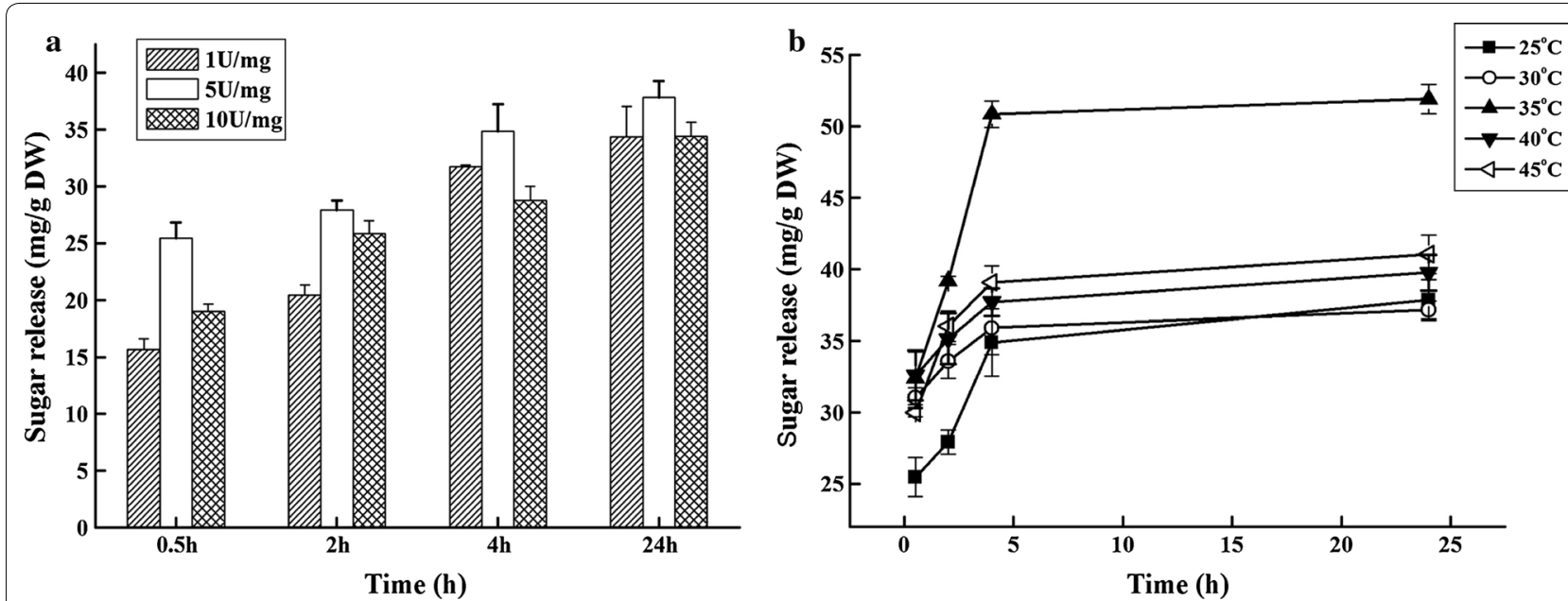

Fig. 5 Optimization of hydrolysis condition toward raw starch from microalgae. a Enzyme dosage. The reaction mixture contained 1-10 U/mg biomass of AmyZ1 and $5 \%$ microalgae biomass. After incubated at $25^{\circ} \mathrm{C}$, the released sugars were measured by the DNS method. $\mathbf{b}$ Reaction temperature. The reaction mixture was incubated at $25-45^{\circ} \mathrm{C}$, containing $5 \%$ microalgae biomass and $5 \mathrm{U} / \mathrm{mg}$ biomass of AmyZ1. All the results were the average of triplicate experiments

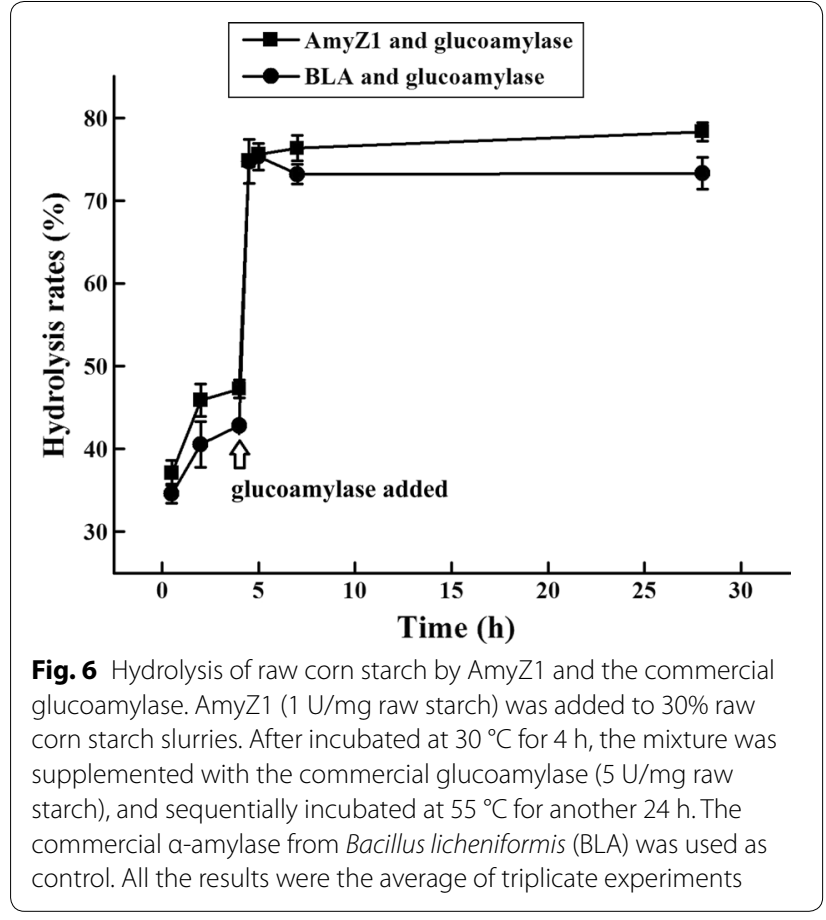

$28 \mathrm{~h}$ incubation. In comparison, the commercial BLA showed a hydrolysis rate of $42.8 \pm 0.5 \%$ on raw corn starch after incubation at $30{ }^{\circ} \mathrm{C}$ for $4 \mathrm{~h}$. Furthermore, although the dosages of AmyZ1 and BLA were $1 \mathrm{U} / \mathrm{mg}$ raw starch, they are different in protein concentration. Due to a higher specific activity, only $0.13 \mathrm{mg}$ AmyZ1 was added into $30 \%$ raw starch slurry, whereas $75 \mathrm{mg}$ of BLA was needed to reach the same activity. $\alpha$-Amylases from B. licheniformis are considered as thermostable enzymes and widely used in starch liquefaction process [6]. Some literatures also reported that the $\alpha$-Amylases from this genus possessed potency of raw starch digesting $[6,16]$. However, when compared with commercial $\alpha$-amylase BLA, AmyZ1 exhibited higher efficiency towards $30 \%$ raw corn starch, with less amount of AmyZ1 required. These properties of AmyZ1 bring more savings to the manufacturers and eventually, the consumers.

Conventionally, raw corn starch processed in bioethanol industries is sequentially gelatinized at about $100{ }^{\circ} \mathrm{C}$, liquefied with thermophilic $\alpha$-amylase at 95-105 ${ }^{\circ} \mathrm{C}$ for $2-3 \mathrm{~h}$, and treated with glucoamylase at $50-60{ }^{\circ} \mathrm{C}$ for about $50 \mathrm{~min}$. These procedures not only require a large amount of energy input, but also give a low yield, with only approximately $50 \%$ of corn starch hydrolyzed within about 3-4 h (personal communication with a technical director from Anhui ANTE food Co., Ltd.). When using AmyZ1 paired with the commercial glucoamylase, about $75 \%$ of raw starch was hydrolyzed within $4.5 \mathrm{~h}$ at $30{ }^{\circ} \mathrm{C}$, without the need of gelatinization step. As a result, the combination of AmyZ1 and glucoamylase will sharply decrease the energy cost and eventually the production cost.

\section{Action pattern of AmyZ1 on raw starches}

To further explore the action pattern of AmyZ1 on raw starches, digested raw starch granules were visualized with a Scanning Electron Microscope (SEM) (Additional file 7: Figure S5). The untreated starch granules remained intact and smooth. However, raw rice starch displayed 
inhomogeneous holes with different sizes, depth, and width after enzymatic hydrolysis. For raw wheat and corn starches, deeper and smaller holes were observed on the surface of the starch granules. SEM images confirmed that AmyZ1 hydrolyzed the raw starch granules in a random attack mode.

The soluble hydrolysis end products were analyzed using HPLC with $30 \%$ raw starches as the substrates (Additional file 8: Table S3). The end products of raw rice starch after hydrolysis were similar to those from raw corn starch, with maltose (G2), maltotriose (G3), and maltopentaose (G5) as the predominant composition, followed by glucose (G1) and maltotetraose (G4). These results suggested that AmyZ1 was a classical saccharifying-type $\alpha$-amylases, same to those from $B$. licheniformis NH1 [40] and G. thermoleovorans [17]. On the other hand, when raw wheat starch was used as the substrate, G2 was the major final oligosaccharide, accounting for approximately $90 \%$ of the end products. This was distinct from previous studies of $\alpha$-amylases on raw wheat starch, of which the end products were various maltooligosaccharides [12, 50, 52]. The action pattern of AmyZ1 towards raw wheat starch makes it as a maltose-forming enzyme, like the enzyme from $B$. acidicola [11]. According to Roy et al., high maltose-forming enzymes are of high demands in the baking industry [50].

\section{Conclusions}

A novel $\alpha$-amylase AmyZ1 with raw starch hydrolysis ability was cloned from a sediment bacterium Pontibacillus sp. ZY. Remarkably, AmyZ1 possessed significantly higher specific activity toward raw starches than other reported $\alpha$-amylases. In addition to that, AmyZ1 efficiently hydrolyzed raw starches from terrestrial plants and that derived from microalgae. Considering its rapid hydrolysis toward raw starches at a lower temperature, AmyZ1 is undoubtedly a promising candidate for enzymatic hydrolysis toward high concentration raw starch slurries.

\section{Methods}

\section{Materials and chemicals}

The sediment sample from Yongxing island in the South China Sea (sampling site: $16^{\circ} 8^{\prime} 50^{\prime \prime} \mathrm{N}, 112^{\circ} 2^{\prime} 60^{\prime \prime} \mathrm{E}$ ) was collected in Sep 2016 and stored at $-20{ }^{\circ} \mathrm{C}$ until use. Soluble starch, amylose, amylopectin, $\alpha$-cyclodextrin, and $\beta$-cyclodextrin were obtained from Sigma Chemical Co. (St. Louis, MO, USA). Rice, corn, and wheat were purchased from the local supermarket (RT-Mart, Hefei, China). They were crushed using food grinder and milled with mortar. The algae powder of C. pyrenoidosa was purchased from Guangyu Biological Technology Co., Ltd. (Shanghai, China). The commercial glucoamylase of $A$. niger was purchased from Aladdin Biological Technology Co., Ltd. (Shanghai, China). The commercial $\alpha$-amylase from B. licheniformis (BLA, named Termamyl ${ }^{\circledR} 120$ ) was obtained from Sigma Chemical Co. (St. Louis, MO, USA). Other chemicals and reagents were of analytical grade.

\section{Screening for positive clones with amylolytic activity}

One gram of wet sediment was mixed with $9 \mathrm{~mL}$ of sterilized seawater, and was shaken at $200 \mathrm{rpm}, 15^{\circ} \mathrm{C}$ for $2 \mathrm{~h}$. The suspension was subjected to the standard dilutionto-extinction method to $10^{-6}$. Aliquots of $100 \mu \mathrm{L}$ dilutions were spread on the screening agar plates (contained $0.2 \%$ soluble starch, $0.5 \%$ tryptone, $0.1 \%$ yeast extract, $3.3 \%$ synthetic sea salt, and $1.5 \%$ agar) and incubated at $15{ }^{\circ} \mathrm{C}$ for $1-3$ days. Then the clones were flooded with Lugol's iodine solution. Positive clones were screened out by the formation of a halo around the clones against the purple background.

\section{Genomic DNA extraction and analysis of $16 \mathrm{~S}$ rRNA gene}

Positive strains were cultured in $5 \mathrm{~mL}$ standard synthetic sea salt medium (Sigma-Aldrich) and incubated at $37{ }^{\circ} \mathrm{C}, 180 \mathrm{rpm}$ for $12 \mathrm{~h}$. Genomic DNA of the positive strains was extracted according to the manufacturer's instructions of the kit (Sangon Biotech Co., Ltd; Shanghai, China) and was used as the template. Amplification of the 16S rRNA gene was performed using eubacteria primers of Bact-27F (5'-AGAGTTTGATCMTGGCTC AG-3') and Bact-1492R (5'-GGTTACCTTGTTACGACT $\left.\mathrm{T}-3^{\prime}\right)$. The PCR products were cloned into the pGEM-T vector (Promega Corporation, WI, USA) and sequenced (Sangon Biotech Co., Ltd.; Shanghai, China). Then, the Blastn (https://www.ncbi.nlm.nih.gov/) search was carried out to determine the most closely related species.

\section{Cloning, expression, denaturation and renaturation of AmyZ1}

To clone AmyZ1 from Pontibacillus sp. ZY genome, a degenerate primer pair of AmyF (5'-catatgYTNGGNATNWSNTTYGTNYTN-3', Nde I digestion site underlined) and AmyR (5'-ctcgagYTTYTGYTTRTA NACNSWNACNSW-3', XhoI digestion site underlined) were designed according to the $\alpha$-amylase (WP_036770168) from P. halophilus JSM 076056. After digested with NdeI and $X h o I$, the PCR product was ligated into pET22b(+) (Novagen, Madison, WI) to generate $\mathrm{pET} 22 \mathrm{~b}(+)-A m y Z 1$.

Escherichia coli BL21 (DE3) containing pET22b $(+)$-AmyZ1 was cultivated in $1 \mathrm{~L}$ Luria Broth containing $100 \mathrm{mg} / \mathrm{L}$ ampicillin at $37^{\circ} \mathrm{C}$ until $O D_{600}$ reached 0.6 . Protein expression was induced by the addition of $0.2 \mathrm{mM}$ IPTG and the culture was further incubated at $150 \mathrm{rpm}$ and $37{ }^{\circ} \mathrm{C}$ for $4 \mathrm{~h}$. Cells were collected at 
$4{ }^{\circ} \mathrm{C}$ by centrifugation at $8000 \times g$ for $10 \mathrm{~min}$ and resuspended in cold Tris- $\mathrm{HCl}$ buffer $(50 \mathrm{mM}, \mathrm{pH}$ 8.0). Then the cells were disrupted by sonication, followed by centrifugation at $10,000 \times g$ and $4{ }^{\circ} \mathrm{C}$ for $30 \mathrm{~min}$ to isolate AmyZ1 inclusion bodies.

To refold the protein, AmyZ1 inclusion bodies from 1 $\mathrm{L}$ cell cultures were dissolved in $75 \mathrm{~mL}$ Tris- $\mathrm{HCl}$ buffer (50 mM, pH 8.0) containing $8 \mathrm{M}$ urea. Then $\mathrm{dH}_{2} \mathrm{O}$ supplemented with $10 \mathrm{mM} \mathrm{CaCl}_{2}$ was added until the final concentration of urea reached $1 \mathrm{M}$. After kept at $4{ }^{\circ} \mathrm{C}$ for $10 \mathrm{~h}$, the supernatant was pooled and dialyzed against $\mathrm{Na}_{2} \mathrm{HPO}_{4}-\mathrm{KH}_{2} \mathrm{PO}_{4}$ buffer $(50 \mathrm{mM}, \mathrm{pH}$ 6.5) containing $1 \mathrm{mM} \mathrm{CaCl}_{2}$ for overnight. All experiments were performed at $4{ }^{\circ} \mathrm{C}$.

The refolded protein was evaluated by SDS-PAGE with $15 \%$ polyacrylamide gel. Protein concentration was determined by $\mathrm{BCA}$ method according to the protocol (Thermo Fisher Scientific, Waltham, MA, USA). To determine the molecular mass of native protein, the purified protein was analyzed by Native-PAGE using the precast polyacrylamide gel (4-20\%; Bio-Rad Laboratories, Inc.), and the unstained protein marker as the standard (Thermo Fisher Scientific, Waltham, MA, USA).

\section{Bioinformatic analysis of AmyZ1}

The presence of a putative signal peptide was predicted using SignalP 4.0 program (http://www.cbs.dtu.dk/servi ces/SignalP/) and simple modular architecture research tool (SMART, http://smart.embl-heidelberg.de/). To classify AmyZ1 into a subfamily, multiple sequence alignment of AmyZ1 with other GH13 $\alpha$-amylase sequences was performed using ClustalX 2.0. The phylogenetic tree was constructed by MEGA 7 using the Maximum Likelihood method. The conserved regions of enzymes were displayed using GENEDOC (http://www.psc.edu/biome $\mathrm{d} /$ genedoc).

The three-dimensional structure of AmyZ1 was generated using the automated Swiss-Model protein modeling server (http://swissmodel.expasy.org) with $\alpha$-amylase from B. licheniformis (PDB code: 1BLI) as the template. The structures were visualized using Pymol (http://www. pymol.org/).

\section{Enzyme assay}

The enzyme activity of AmyZ1 was determined by measuring the reducing sugars released from the hydrolysis of raw starches base on the dinitrosalicylic acid (DNS) assay. The reaction mixture contained $30 \mu \mathrm{L}$ enzyme solution, and $570 \mu \mathrm{L} \mathrm{Na} \mathrm{NPO}_{4}-\mathrm{KH}_{2} \mathrm{PO}_{4}$ buffer ( $50 \mathrm{mM}, \mathrm{pH} 7.0$ ) supplemented with $1 \%$ raw rice starch and $1 \mathrm{mM} \mathrm{CaCl}_{2}$.
After incubating the mixture at $35{ }^{\circ} \mathrm{C}$ for $10 \mathrm{~min}$, the reaction was stopped by adding $300 \mu \mathrm{L}$ of DNS. The reaction mixture was then heated in boiling water for $15 \mathrm{~min}$. The amount of reducing sugars released was monitored at $540 \mathrm{~nm}$. One unit of amylase activity was defined as the amount of enzyme needed to release $1 \mu \mathrm{mol}$ of reducing sugars as maltose per minute under standard assay conditions described above. Assays with heat treated AmyZ1 was used as control.

\section{Effects of temperature and $\mathrm{pH}$ on the activity and stability of AmyZ1}

The effect of temperature on AmyZ1 activity was determined at temperatures ranging from 20 to $70{ }^{\circ} \mathrm{C}$ using raw rice starch as the substrate. The optimum $\mathrm{pH}$ of AmyZ1 was examined in the $\mathrm{pH}$ range of 4.0 to 8.5 at $35{ }^{\circ} \mathrm{C}$ in citrate- $\mathrm{Na}_{2} \mathrm{HPO}_{4}$ buffer $(50 \mathrm{mM}$, pH $5.0-8.5)$ and $\mathrm{Na}_{2} \mathrm{HPO}_{4}-\mathrm{KH}_{2} \mathrm{PO}_{4}$ buffer $(50 \mathrm{mM}$, pH 6.0-7.5). In the absence of $\mathrm{Ca}^{2+}$, the thermostability was determined by incubating the enzyme in $\mathrm{Na}_{2} \mathrm{HPO}_{4}-\mathrm{KH}_{2} \mathrm{PO}_{4}$ buffer $(50 \mathrm{mM}, \mathrm{pH} 7.0)$ at $20-35^{\circ} \mathrm{C}$. At appropriate intervals, the residual activity was measured using the DNS method as mentioned above. The pH stability of AmyZ1 without $\mathrm{Ca}^{2+}$ was determined by dispersing the enzyme in $\mathrm{Na}_{2} \mathrm{HPO}_{4}-\mathrm{KH}_{2} \mathrm{PO}_{4}$ buffer of $\mathrm{pH} 6.0,6.5$, and 7.0, and the residual activities were measured at appropriate intervals.

\section{Effects of metal ions and chemicals on enzyme activity and stability}

To evaluate the influence of $\mathrm{Ca}^{2+}$ and $\mathrm{Na}^{+}$on the activity of AmyZ1, additional supplement of $\mathrm{CaCl}_{2}$ and $\mathrm{NaCl}$ was included in the reaction mixture that consisted of raw rice starch, appropriate volume of enzyme, and $\mathrm{Na}_{2} \mathrm{HPO}_{4}-\mathrm{KH}_{2} \mathrm{PO}_{4}$ buffer (50 mM, pH 7.0). To determine the thermostability in the presence of $\mathrm{Ca}^{2+}$ or $\mathrm{Na}^{+}$, the enzyme was mixed with different concentrations of $\mathrm{CaCl}_{2}$ or $\mathrm{NaCl}$ and incubated at 30 or $35^{\circ} \mathrm{C}$. The residual activities were measured at appropriate intervals.

The effects of other metal ions and chemicals on the activity of AmyZ1 were evaluated under the standard assay conditions with additional supplement of 1,5 or $10 \mathrm{mM}$ $\mathrm{Mn}^{2+}, \mathrm{Cu}^{2+}, \mathrm{K}^{+}, \mathrm{Mg}^{2+}, \mathrm{Zn}^{2+}$, and EDTA. In control, the reaction mixture contained appropriate volume of enzyme and $\mathrm{Na}_{2} \mathrm{HPO}_{4}-\mathrm{KH}_{2} \mathrm{PO}_{4}$ buffer (50 mM, pH 7.0) supplemented with rice raw starch as the substrate. The enzyme activity determined in the control were defined as $100 \%$. In the reaction mixture containing additional metal ions, the enzyme activity was determined and the relative activities were calculated. The relative activities were defined as the activity in the presence of additional metal ions relative to that of control. 


\section{Substrate specificity}

The substrate specificity was determined under the standard assay condition using $1 \%(\mathrm{w} / \mathrm{v})$ raw starch from various origins including rice, corn, wheat, barley, potato, and bean. Soluble starch, amylose, amylopectin, pullulan, $\alpha$-cyclodextrin, and $\beta$-cyclodextrin were also used as the substrates.

The kinetic constants of AmyZ1, including $K_{\mathrm{m}}$ and $V_{\max }$, were measured using raw rice starch as the substrate based on the DNS assay. The reaction was performed by incubating the enzyme in $\mathrm{Na}_{2} \mathrm{HPO}_{4}-\mathrm{KH}_{2} \mathrm{PO}_{4}(50 \mathrm{mM}$, pH 7.0) supplemented with varying concentrations of raw rice starch $(1.0-20 \mathrm{mg} / \mathrm{mL})$. The reaction was performed at $35^{\circ} \mathrm{C}$ for $10 \mathrm{~min}$. The kinetic parameters were calculated by fitting the experimental data to Lineweaver-Burt equation of the Michaelis-Menten model using Origin 8.0.

\section{Hydrolysis condition optimization towards high concentration raw starches}

Hydrolysis activity of AmyZ1 toward high concentration raw starch was evaluated using raw starches from terrestrial plants including rice, corn, and wheat, as well as aquatic algae C. pyrenoidosa. With raw rice, corn, and wheat starch as the substrates, factors including enzyme unit (0.5-10 U/mg starch), substrate concentration (20\% or $30 \%, \mathrm{w} / \mathrm{v})$, reaction temperature $\left(20-35^{\circ} \mathrm{C}\right)$, and reaction time $(1-24 \mathrm{~h})$ were optimized using the single factor analysis. Reactions were carried out in a mixture containing appropriate volume of enzyme, raw starches, and $\mathrm{Na}_{2} \mathrm{HPO}_{4}-\mathrm{KH}_{2} \mathrm{PO}_{4}$ buffer ( $50 \mathrm{mM}, \mathrm{pH}$ 7.0) supplemented with $1 \mathrm{mM} \mathrm{CaCl}_{2}$.

Specially, when using raw starch from C. pyrenoidosa as the substrate, the $C$. pyrenoidosa powder was suspended in $\mathrm{Na}_{2} \mathrm{HPO}_{4}-\mathrm{KH}_{2} \mathrm{PO}_{4}$ buffer $(50 \mathrm{mM}, \mathrm{pH} 7.0)$ to a final concentration of $5 \%(\mathrm{w} / \mathrm{v})$. The mixture was disrupted by sonication for $30 \mathrm{~min}$ at a frequency of $40 \mathrm{kHz}$ and an acoustic power up to $450 \mathrm{~W}$ [60]. Five percent $(\mathrm{w} / \mathrm{v})$ biomass was incubated with AmyZ1 with the dosage of 1, 5 and $10 \mathrm{U} /$ $\mathrm{mg}$ biomass. The mixture was incubated at 25 to $45^{\circ} \mathrm{C}$ and the reducing sugars in supernatant were assayed by the DNS method at appropriate intervals.

The extent of raw starch hydrolysis was calculated using the following formula:

\section{Hydrolysis of raw corn starch by AmyZ1 and the commercial glucoamylase}

Thirty percent $(\mathrm{w} / \mathrm{v})$ raw corn starch slurries were employed to evaluate the combined hydrolysis effect of $\alpha$-amylase AmyZ1 and the commercial glucoamylase from A. niger. The purified AmyZ1 (1 U/mg raw starch) was added to $30 \%$ raw corn starch slurries. The reaction mixture was incubated at $30^{\circ} \mathrm{C}$ for $4 \mathrm{~h}$ with shaking at $150 \mathrm{rpm}$. Then, the mixture was supplemented with the commercial glucoamylase (5 U/mg raw starch) and sequentially incubated at $55{ }^{\circ} \mathrm{C}$ for another $24 \mathrm{~h}$. Furthermore, the commercial $\alpha$-amylase from $B$. licheniformis (BLA) was used as control to hydrolyze raw corn starch performed as mentioned above. At appropriate intervals, the samples were withdrawn and the reducing sugars were measured by the DNS method using glucose as the standard. The rates of hydrolysis were calculated according to the formula described above.

\section{Scanning electron microscopy}

The raw starch shape before and after hydrolysis was visualized using a Scanning Electron Microscope (SEM, HITACHI S4800, Japan). Briefly, the reaction was conducted using AmyZ1 (5 U/mg starch) and 5\% raw starches from various sources including rice, corn, and wheat. After incubation at $30^{\circ} \mathrm{C}$ for $30 \mathrm{~min}$, the mixture was centrifuged at $8000 \times g$ to recover the pellets. Then the pellets were washed with pure ethanol for three times, followed by drying at $35{ }^{\circ} \mathrm{C}$ to a constant weight. The samples were fixed on a specimen holder using a silver plate and coated with Pt using Ion Sputter E-1010 at $5.0 \mathrm{kV}$ and $20 \mathrm{~mA}$ for $40 \mathrm{~s}$. The specimens were then viewed with SEM.

\section{Analysis of the hydrolyzed products}

The hydrolytic products of AmyZ1 from raw starches were determined using high-performance liquid chromatography (HPLC; Agilent Corp., Palo Alto, CA) equipped with a Carbohydrate ES column $(5 \mu \mathrm{m}, 250 \times 4.6 \mathrm{~mm}$, Alltech) and an evaporative light scattering detector. The mobile phase was acetonitrile and water $(55: 45, \mathrm{v} / \mathrm{v})$ with a flow rate of $1.0 \mathrm{~mL} / \mathrm{min}$ at $25^{\circ} \mathrm{C}$. Glucose (G1), maltose (G2), maltotriose (G3), maltotetraose (G4), and maltopentaose (G5) were used as standards.

$$
\begin{aligned}
\text { Hydrolysis rates }(\%)= & {\left[\text { reducing sugars }\left(\mathrm{mg} \mathrm{mL}^{-1}\right) / \text { initial weight of raw } \operatorname{starch}\left(\mathrm{mgmL}^{-1}\right)\right] } \\
& \times 0.9 \times 100
\end{aligned}
$$

The factor 0.9 (referred to $162 / 180$ ) is the conversion factor caused by hydrolysis reaction [17].

\section{Nucleotide sequences accession number}

The partial 16S rRNA gene sequence of Pontibacillus sp. $\mathrm{ZY}$ and AmyZ1 amino acid sequence have been deposited in the GenBank database with the accession number MH279661 and AXV43605, respectively. 


\section{Additional files}

Additional file 1: Figure S1. Alignment of the amino acid sequences of AmyZ1 and other known a-amylases. The four conserved regions (region I-region IV) were boxed. The key catalytic residues were indicated below the sequences by a black triangle. 1BLI: a-amylase from Bacillus licheniformis; ADE44086: a-amylase from Bacillus amyloliquefaciens; WP_058836133: a-amylase from Luteimonas abyssi.

Additional file 2: Figure S2. Phylogenic analysis of AmyZ1 and other reported a-amylases of GH13 family. The protein sequences of different subfamilies were retrieved from CAZy database. The tree was built using Maximum Likelihood method of the program MEGA 7. The bootstrap values were calculated based on 1000 replicates.

Additional file 3: Figure S3. Homology model structure of AmyZ1. The structure of AmyZ1 was constructed based on its closest structural relative Bacillus licheniformis a-amylase (PDB code: 1BLI). The domains were colored as follows: A, red; B, green; C, blue.

Additional file 4: Table S1. Denaturation and renaturation of a-amylase AmyZ1.

Additional file 5: Figure S4. Effects of $\mathrm{NaCl}$ and $\mathrm{CaCl}_{2}$ on AmyZ1 stability. The assays were performed by incubating the enzyme at $30{ }^{\circ} \mathrm{C}$ in $\mathrm{Na}_{2} \mathrm{HPO}_{4}-\mathrm{KH}_{2} \mathrm{PO}_{4}$ buffer (50 mM, pH 7.0) containing additional $\mathrm{CaCl}_{2}$ or $\mathrm{NaCl}$. The residual activities were determined at various time intervals.

Additional file 6: Table S2. Effects of metal ions on enzyme activity.

Additional file 7: Figure S5. Scanning electron microscopy of raw starch granules hydrolyzed by AmyZ1. a, c and e: raw rice, corn, and wheat starch before hydrolysis; $b, d$ and f: raw rice, corn, and wheat starch treated with AmyZ1.

Additional file 8: Table S3. Hydrolysis products of raw starches catalyzed by AmyZ1.

\section{Abbreviations}

DW: dry weight of the biomass; BLAST: basic local alignment search tool; SMART: simple modular architecture research tool; DNS: dinitrosalicylic acid; IPTG: isopropyl $\beta$-D-1-thiogalactopyranoside; SDS-PAGE: sodium dodecyl sulfate polyacrylamide gel electrophoresis; BLA: the commercial a-amylase of Bacillus licheniformis; SEM: scanning electron microscope; HPLC: high-performance liquid chromatography; G1: glucose; G2: maltose; G3: maltotriose; G4: maltotetraose; G5: maltopentaose.

\section{Authors' contributions}

WF wrote and edited the manuscript. SX carried out the experiments and helped to revise the manuscript. PD screened the positive clones with amylolytic activity. XZ and XW performed the analysis of sequence and structure. $Y X$ and $Z F$ revised the manuscript. All authors read and approved the final manuscript.

\section{Author details}

${ }^{1}$ School of Life Sciences, Anhui University, Hefei 230601, Anhui, China. ${ }^{2}$ Anhui Key Laboratory of Modern Biomanufacturing, Hefei 230601, Anhui, China. ${ }^{3}$ Anhui Provincial Engineering Technology Research Center of Microorganisms and Biocatalysis, Hefei 230601, Anhui, China. ${ }^{4}$ Department of Chemistry \& Biochemistry, Florida International University, Miami, FL 33199, USA.

\section{Acknowledgements}

We would like to appreciate Anhui ANTE food Co., Ltd. for providing data related to bioethanol production processes.

\section{Competing interests}

The authors declare that they have no competing interests.

\section{Availability of data and materials}

All data generated or analyzed during this study are included in this published article and its additional files.
Consent for publication

All authors consent for publication.

\section{Ethics approval and consent to participate}

Not applicable.

\section{Funding}

This work was supported by the National Key Research and Development Program (2018YFC0311106); the Science and Technology Major Projects of Anhui province (17030701059); the Natural Science Foundation of the Department of Education of Anhui Province (KJ2017A020).

\section{Publisher's Note}

Springer Nature remains neutral with regard to jurisdictional claims in published maps and institutional affiliations.

Received: 13 January 2019 Accepted: 12 April 2019

Published online: 23 April 2019

\section{References}

1. Deya TB, Kumara A, Rintu B, Chandna P, Kuhada RC. Improvement of microbial a-amylase stability: strategic approaches. Process Biochem. 2016;51:1380-90.

2. Lei Y, Peng H, Wang Y, Liu Y, Han F, Xiao Y, Gao Y. Preferential and rapid degradation of raw rice starch by an a-amylase of glycoside hydrolase subfamily GH13_37. Appl Microbiol Biotechnol. 2012;94:1577-84.

3. Xu QS, Yan YS, Feng JX. Efficient hydrolysis of raw starch and ethanol fermentation: a novel raw starch-digesting glucoamylase from Penicillium oxalicum. Biotechnol Biofuels. 2016:9:216.

4. Kalpana BJ, Pandian SK. Halotolerant, acid-alkali stable, chelator resistant and raw starch digesting a-amylase from a marine bacterium Bacillus subtilis S8-18. J Basic Microbiol. 2014;54:802-11.

5. Sun H, Zhao P, Ge X, Xia Y, Hao Z, Liu J, Peng M. Recent advances in microbial raw starch degrading enzymes. Appl Biochem Biotechnol. 2010;160:988-1003.

6. Afrisham S, Badoei-Dalfard A, Namaki-Shoushtari A, Karami Z. Characterization of a thermostable, $\mathrm{CaCl}_{2}$-activated and raw-starch hydrolyzing alpha-amylase from Bacillus licheniformis AT70: production under solid state fermentation by utilizing agricultural wastes. J Mol Catal B Enzym. 2016;132:98-106.

7. Moshi AP, Hosea KM, Elisante E, Mamo G, Önnby L, Nges IA. Production of raw starch-degrading enzyme by Aspergillus sp. and its use in conversion of inedible wild cassava flour to bioethanol. J Biosci Bioeng. 2016:121:457-63.

8. Li Y, Shi G, Wang W, Wang Z. A newly isolated Rhizopus microsporus var. chinensis capable to secret amyloytic enzymes with raw-starch-digesting activity. J Microbiol Biotechnol. 2010;20:383-90.

9. lefuji $\mathrm{H}$, Chino M, Kato M, limura Y. Raw-starch-digesting and thermostable a-amylase from the yeast Cryptococcus sp. S-2: purification, characterization, cloning and sequencing. Biochem J. 1996;318:989-96.

10. Gangadharan D, Nampoothiri KM, Sivaramakrishnan S, Pandey A. Biochemical characterization of raw-starch-digesting alpha amylase purified from Bacillus amyloliquefaciens. Appl Biochem Biotechnol. 2009;158:653-62

11. Sharma A, Satyanarayana T. Cloning and expression of acidstable, high maltose-forming, $\mathrm{Ca}^{2+}$-independent a-amylase from an acidophile Bacillus acidicola and its applicability in starch hydrolysis. Extremophiles. 2012;16:515-22.

12. Mehta D, Satyanarayana T. Biochemical and molecular characterization of recombinant acidic and thermostable raw-starch hydrolysing a-amylase from an extreme thermophile Geobacillus thermoleovorans. J Mol Catal B Enzym. 2013:85:229-38.

13. Li S, Zuo Z, Niu D, Singh S, Permaul K, Prior BA, Shi G, Wang Z. Gene cloning, heterologous expression, and characterization of a high maltoseproducing a-amylase of Rhizopus oryzae. Appl Biochem Biotechnol. 2011:164(5):581-92. 
14. Wang YC, Zhao N, Ma JW, Liu J, Yan QJ, Jiang ZQ. High-level expression of a novel a-amylase from Thermomyces dupontii in Pichia pastoris and its application in maltose syrup production. Int J Biol Macromol. 2019;127:683-92.

15. Zhang Q, Han Y, Xiao H. Microbial a-amylase: a biomolecular overview. Process Biochem. 2017;53:88-101.

16. Slavić MŠ, Pešić $M, V$ Vujčić Z, Božić N. Overcoming hydrolysis of raw corn starch under industrial conditions with Bacillus licheniformis ATCC 9945a a-amylase. Appl Microbiol Biotechnol. 2016;100:2709-19.

17. Jiang T, Cai M, Huang M, He H, Lu J, Zhou X, Zhang Y. Characterization of a thermostable raw-starch hydrolyzing a-amylase from deep-sea thermophile Geobacillus sp. Protein Expr Purif. 2015;114:15-22.

18. Mehta D, Satyanarayana T. Domain C of thermostable a-amylase of Geobacillus thermoleovorans mediates raw starch adsorption. Appl Microbiol Biotechnol. 2014;98:4503-19.

19. Goyal N, Gupta JK, Soni SK. A novel raw starch digesting thermostable a-amylase from Bacillus sp. I-3 and its use in the direct hydrolysis of raw potato starch. Enzym Microb Technol. 2005;37:723-34.

20. Puspasari F, Radjasa OK, Noer AS, Nurachman Z, Syah YM, Maarel M, Dijkhuizen L, Janeček S, Natalia D. Raw starch-degrading a-amylase from Bacillus aquimaris MKSC 6.2: isolation and expression of the gene, bioinformatics and biochemical characterization of the recombinant enzyme. J Appl Microbiol. 2013;114:108-20.

21. Tan TC, Mijts BN, Swaminathan K, Patel BK, Divne C. Crystal structure of the polyextremophilic alpha-amylase AmyB from Halothermothrix orenii: details of a productive enzyme-substrate complex and an $\mathrm{N}$ domain with a role in binding raw starch. J Mol Biol. 2008;378:852-70.

22. Peng $H$, Chen M, Yi L, Zhang X, Wang M, Xiao Y, Zhang N. Identification and characterization of a novel raw-starch-degrading a-amylase (AmyASS) from the marine fish pathogen Aeromonas salmonicida ssp. Salmonicida. J Mol Catal B Enzym. 2015;119:71-7.

23. Lim JM, Jeon CO, Song SM, Kim C. Pontibacillus chungwhensis gen. nov., sp. nov., a moderately halophilic Gram-positive bacterium from a solar saltern in Korea. Int J Syst Evol Microbiol. 2005;55(Pt 1):165-70.

24. Chen YG, Zhang YQ, Xiao HD, Liu ZX, Yi LB, Shi JX, Zhi XY, Cui XL, Li WJ. Pontibacillus halophilus sp. nov., a moderately halophilic bacterium isolated from a sea urchin. Int J Syst Evol Microbiol. 2009;59(Pt 7):1635-9.

25. Huang J, Qiao ZX, Tang JW, Wang G. High quality draft genome sequence of the moderately halophilic bacterium Pontibacillus yanchengensis Y32(T) and comparison among Pontibacillus genomes. Stand Genomic Sci. 2015;10:93.

26. Porter JL, Manning J, Sabatini S, Tavanti M, Turner NJ, Flitsch SL. Characterisation of CYP102A25 from Bacillus marmarensis and CYP102A26 from Pontibacillus halophilus: P450 homologues of BM3 with preference towards hydroxylation of medium-chain fatty acids. Chem Biochem. 2018;19:513-20.

27. Mageswari A, Subramanian P, Chandrasekaran S, Sivashanmugam K, Babu S, Gothandam KM. Optimization and immobilization of amylase obtained from halotolerant bacteria isolated from solar salterns. J Gen Eng Biotechnol. 2012;10:201-8.

28. Janecek Š, Svensson B, MacGregor EA. a-Amylase: an enzyme specificity found in various families of glycoside hydrolases. Cell Mol Life Sci. 2014:71:1149-70.

29. Homaeia A, Ghanbarzadeh M, Monsef F. Biochemical features and kinetic properties of a-amylases from marine organisms. Int J Biol Macromol. 2016;83:306-14.

30. Wu G, Qin Y, Cheng Q. Liu Z Characterization of a novel alkali-stable and salt-tolerant a-amylase from marine bacterium Zunongwangia profunda. $J$ Mol Catal B Enzym. 2014;110:8-15.

31. Zhang JW, Zeng RY. Purification and characterization of a cold-adapted alpha-amylase produced by Nocardiopsis sp. 7326 isolated from Prydz Bay, Antarctic. Mar Biotechnol (NY). 2008;10(1):75-82.

32. Lu M, Wang S, Fang Y, Li H, Liu S, Liu H. Cloning, expression, purification, and characterization of cold-adapted a-amylase from Pseudoalteromonas arctica GS230. Protein J. 2010;29(8):591-7.

33. Xie BB, Bian F, Chen XL, He HL, Guo J, Gao X, Zeng YX, Chen B, Zhou BC, Zhang YZ. Cold adaptation of zinc metalloproteases in the thermolysin family from deep sea and arctic sea ice bacteria revealed by catalytic and structural properties and molecular dynamics: new insights into relationship between conformational flexibility and hydrogen bonding. J Biol Chem. 2009;284(14):9257-69.
34. Dumorné K, Córdova DC, Astorga-Eló M, Renganathan P. Extremozymes: a potential source for industrial applications. J Microbiol Biotechnol. 2017;27(4):649-59.

35. Li Z, Duan X, Wu J. Improving the thermostability and enhancing the $\mathrm{Ca}^{2+}$ binding of the maltohexaose-forming a-amylase from Bacillus stearothermophilus. J Biotechnol. 2016;222:65-72.

36. Machius M, Wiegand G, Huber R. Crystal structure of calciumdepleted Bacillus licheniformis a-amylase at $2.2 \AA$ resolution. J Mol Biol. 1995;246:545-59.

37. Brzozowski AM, Lawson DM, Turkenburg JP, Bisgaard-Frantzen H, Svendsen A, Borchert TV, Dauter Z, Wilson KS, Davies GJ. Structural analysis of a chimeric bacterial a-amylase. High-resolution analysis of native and ligand complexes. Biochemistry. 2000;39:9099-107.

38. Machius M, Declerck N, Huber R, Wiegand G. Activation of Bacillus licheniformis a-amylase through a disorder $\rightarrow$ order transition of the substrate-binding site mediated by a calcium-sodium-calcium metal triad. Structure. 1998;6:281-92.

39. Emampour M, Noghabi KA, Zahiri HS. Molecular cloning and biochemical characterization of a novel cold-adapted alpha-amylase with multiple extremozyme characteristics. J Mol Catal B Enzym. 2015;111:79-86.

40. Hmidet N, Ali NEH, Haddar A, Kanoun S, Alya SK, Nasri M. Alkaline proteases and thermostable $a$-amylase co-produced by Bacillus licheniformis $\mathrm{NH1}$ : characterization and potential application as detergent additive. Biochem Eng J. 2009;47:71-9.

41. Asgher M, Asad MJ, Rahman SU, Legge RL. A thermostable a-amylase from a moderately thermophilic Bacillus subtilis strain for starch processing. J Food Eng. 2007;79:950-5.

42. Song $Q$, Wang Y, Yin C, Zhang XH. LaaA, a novel high-active alkalophilic alpha-amylase from deep-sea bacterium Luteimonas abyssi XH031 (T). Enzyme Microb Technol. 2016;90:83-92.

43. Ali I, Akbar A, Anwar M, Prasongsuk S, Lotrakul P, Punnapayak H. Purification and characterization of a polyextremophilic alpha-amylase from an obligate halophilic Aspergillus penicillioides isolate and its potential for souse with detergents. Biomed Res Int. 2015;2015:245649-57.

44. Aleem B, Rashid MH, Zeb N, Saqib A, Ihsan A, labal M, Ali H. Random mutagenesis of super Koji (Aspergillus oryzae): improvement in production and thermal stability of a-amylases for maltose syrup production. BMC Microbiol. 2018;18(1):200.

45. Trabelsi S, Sahnoun M, Elgharbi F, Ameri R, Ben Mabrouk S, Mezghani M, Hmida-Sayari A, Bejar S. Aspergillus oryzae S2 AmyA amylase expression in Pichia pastoris: production, purification and novel properties. Mol Biol Rep. 2019:46(1):921-32.

46. Galdino AS, Silva RN, Lottermann MT, Alvares AC, de Moraes LM, Torres FA, de Freitas SM, Ulhoa CJ. Biochemical and structural characterization of Amy1: an alpha-Amylase from Cryptococcus flavus expressed in Saccharomyces cerevisiae. Enzyme Res. 2011;2011:157294.

47. Wanderley KJ, Torres FA, Moraes LM, Ulhoa CJ. Biochemical characterization of alpha-amylase from the yeast Cryptococcus flavus. FEMS Microbiol Lett. 2004;231(2):165-9.

48. Hostinová E, Janecek S, Gasperík J. Gene sequence, bioinformatics and enzymatic characterization of a-amylase from Saccharomycopsis fibuligera KZ. Protein J. 2010;29(5):355-64.

49. Božiča N, Ruizb J, López-Santínb J, Vujčič Z. Production and properties of the highly efficient raw starch digesting a-amylase from a Bacillus licheniformis ATCC 9945a. Biochem Eng J. 2011;53:203-9.

50. Roy JK, Mukherjee AK. Applications of a high maltose forming, thermostable a-amylase from an extremely alkalophilic Bacillus licheniformis strain AS08E in food and laundry detergent industries. Biochem Eng J. 2013;77:220-30.

51. Sameh M, Kamoun A, Moulis C, Remaud-Simeon M, Ghribi D, Châabouni SE. A new raw-starch-digesting a-amylase: production under solid-state fermentation on crude millet and biochemical characterization. J Microbiol Biotechnol. 2013;23:489-98.

52. Shivlata L, Satyanarayana T. Characteristics of raw starch-digesting a-amylase of Streptomyces badius DB-1 with transglycosylation activity and its applications. Appl Biochem Biotechnol. 2017;181:1283-303.

53. Liu XD, Xu Y. A novel raw starch digesting a-amylase from a newly isolated Bacillus sp. YX-1: Purification and characterization. Bioresour Technol. 2008;99:4315-20. 
54. Li Z, Wu J, Zhang B, Wang F, Ye X, Huang Y, Huang Q, Cui Z. AmyM, a novel maltohexaose-forming a-amylase from Corallococcus sp. strain EGB. Appl Environ Microbiol. 2015;81:1977-87.

55. Shafiei M, Ziaee AA, Amoozegar MA. Purification and biochemical characterization of a novel SDS and surfactant stable, raw starch digesting, and halophilic a-amylase from a moderately halophilic bacterium, Nesterenkonia sp. strain F. Process Biochem. 2010;45:694-9.

56. Tawil G, Viksø-Nielsen A, Rolland-Sabate A, Colonna P, Buléon A. In depth study of a new highly efficient raw starch hydrolyzing a-amylase from Rhizomucor sp. Biomacromol. 2011;12:34-42.

57. Hernández D, Riaño B, Coca M, García-González MC. Saccharification of carbohydrates in microalgal biomass by physical, chemical and enzymatic pre-treatments as a previous step for bioethanol production. Chem Eng J. 2015;262:939-45.
58. Ho SH, Huang SW, Chen CY, Hasunuma T, Kondo A, Chang JS. Bioethanol production using carbohydrate-rich microalgae biomass as feedstock. Bioresour Technol. 2013;135:191-8.

59. Lee OK, Oh YK, Lee EY. Bioethanol production from carbohydrateenriched residual biomass obtained after lipid extraction of Chlorella sp. KR-1. Bioresour Technol. 2015;196:22-7.

60. Haruna R, Danquah MK. Enzymatic hydrolysis of microalgal biomass for bioethanol production. Chem Eng J. 2011;168:1079-84.
Ready to submit your research? Choose BMC and benefit from:

- fast, convenient online submission

- thorough peer review by experienced researchers in your field

- rapid publication on acceptance

- support for research data, including large and complex data types

- gold Open Access which fosters wider collaboration and increased citations

- maximum visibility for your research: over 100M website views per year

At BMC, research is always in progress.

Learn more biomedcentral.com/submissions 